\title{
An appreciative contextual response to Jean-Pierre Wils, 'Is there a future for "medical ethics"?' Just Health as a public theological concern
}

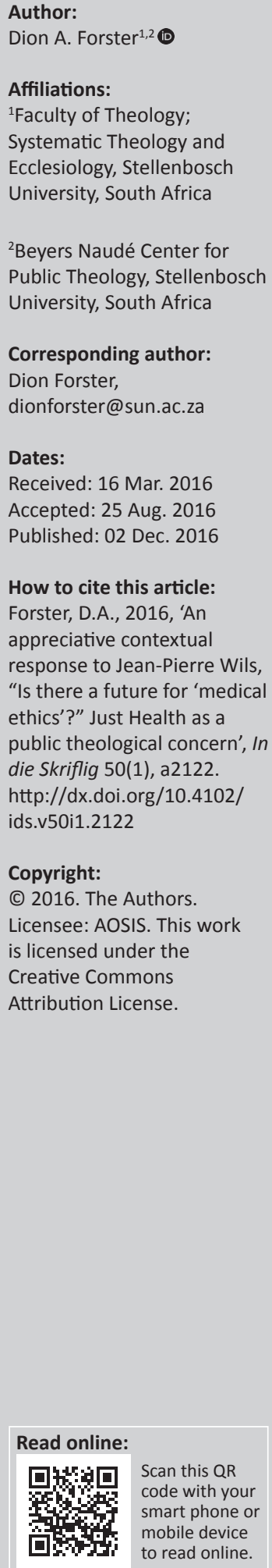

\begin{abstract}
This article takes the form of an appreciative contextual response to the notion of 'just health' that is formulated in Jean-Pierre Wils' article, 'Is there a future for medical ethics?' It approaches the notion of just health in the South African context from a public theological vantage point. The article addresses the issues of justice, care and the future of 'medical ethics' by adopting a position that seeks to constructively engage empire, economics and apathy in relation to just health in South Africa.
\end{abstract}

\section{Introduction}

In his article, 'Is there a future for medical ethics?', Jean-Pierre Wils (2016) offers a clear and convincing argument for a shift in focus from just health care (which focuses on the ethics of health care provision) to just health (the more encompassing view of the relationship between justice and health) as an important consideration for the future of medical ethics.

The central points of his argument are deeply challenging within this context, namely that ethicists shall need to move from a mere focus upon the question of what constitutes 'just health care' to a further reaching consideration of what constitutes 'just health' (Wils 2016:1). He (Wils 2016:2) situates this discussion within the ambit of the political, namely that medical ethicists 'have the tendency to isolate moral conflicts from their social contexts: And for this reason questions of justice play only a minor role there'.

Second, and in relation to the above, the discussion on the social characteristics of health is of critical importance to understanding the complexity and subtlety of developing a thorough medical ethic. The two questions Wils $(2016: 6,10)$ raises to frame this discussion were very helpful: What is the 'good of health' and how is it constituted? and What constitutes 'just health' when it is considered within the context of the social causes related to health and disease?

While Wils' article (2016) was not written for the South African context, it raises a number of critical contextual issues that we face in South Africa. By bringing these issues into conversation with Wils' discussion of the future of medical ethics, one is able to further develop the discourse around medical ethics in the South African context. Hence, this article takes the form of an appreciative contextual response to some of the central aspects of Wils' argument in relation to a particularly South African health care challenge, namely the prevalence of HIV and AIDS. Of course notions of just health could touch upon a much wider range of issues than just this one topic. However, this one issue, namely HIV and AIDS will serve as a vivid example of some of the contextual and intersectional complexities of just health in the South African context. Moreover, this discussion will develop some links between this appreciative contextual reflection and the public theological responsibility of Christians and the church in the South African context.

In 2010 a series of essays written on the subject of HIV and AIDS were collected into a book entitled Christian and positive: Reflections on being Christian in an HIV+ world (Forster 2010a) to use as a tool for theological reflection at an international congress. At the time of writing some of those articles (between 2007 and 2010) Southern Africa was known for having the highest rate of HIV infection and AIDS deaths in the world. Of the 33.2 million persons living with AIDS globally at that point, 22.5 million lived in Sub-Saharan Africa - 'that amounts to $68 \%$ of all HIV+ persons [living] in less than $10 \%$ of the world's geographic land mass' (Forster 2010a:18). It was calculated that approximately 4500 persons in this region died of HIV and AIDS-related medical causes each day. 
This book of Forster (2010a) seeks to address a question of contextual theological importance: How was it possible that such devastation could exist in one of the regions of the world with such a high percentage of self-identified Christians? ${ }^{1}$ Surely the notions of an ethic of justice and an ethic of care, which are important in the Christian faith, would not allow such a situation to exist.

Of course the reality is, as Wils helps us to understand, that complex social, economic, political and gender intersectionality impacts upon both Christian doctrine and Christian ethics. ${ }^{2}$ While Wils (cf. 2016:2) illustrated this complexity in citing a European case study (i.e. the Greek emergency ambulance story), this article will situate the intersectional theological and ethical complexity of 'just health' within a South African story. This narrative serves to illustrate the complexity and importance of medical ethics for the South African context and, in doing so, it aims to engage and explicate some of the points that Wils makes in his article.

\section{Health and justice against the backdrop of South African social issues: Nosipho's story}

Wils (2016:2-3) begins his discussion of the notion of 'just health' by placing it in relief against the backdrop of social issues, viz. 'health as a political issue'. The book (Forster 2010a:9-11), mentioned in the previous section, begins with a South African story that highlights the social, economic, cultural and political intersectionality of 'just health' within the South African context.

\section{No greater gift $^{3}$}

Nosipho is just 13 years old. Tonight she is lying awake next to her 8-year-old brother and 5-year-old sister. Her father named her Nosipho when she was born. She remembers that her name has a very special meaning. Nosipho was born to her proud parents, Mxolisi and Vuyisile, in a remote part of South Africa called Northern KwaZulu-Natal. There was no work for Mxolisi and he went to the city to find work as a labourer on the roads. Mxolisi wanted to live a good life and take care of his family as best as he could. So, he faithfully brought money back to Vuyisile and Nosipho at every opportunity. He and Vuyisile were blessed with a son who they named Andile (meaning 'the family is growing'). They loved their children very much and had great dreams for their future.

However, with each year that passed it became more difficult for Mxolisi to be alone in the city. The months that Mxolisi

1.Nieman $(2010: 37-44)$ notes that $84 \%$ of the South African population identify themselves as belonging to one of the four major religious traditions (Christinaity, Islam, Hinduism and Judaism) of which $79.8 \%$ consider themselves to be Christian. For a thorough theological discussion see Hendriks and Erasmus (2005)

2.See for example Wils' discussion (2016:2) of the intersectional complexity of 'just health' and just health care related through the case study of the Greek Medical center's emergency ambulances.

3.This story was first written as a case study in the book Christian and positive (Forster 2010a:9-11; Barlow et al. 2010:5-8). It also featured as part of a reflection for world AIDS day on 01 December 2010 under the heading World AIDS day - I am positive (Forster 2010b) and Vuyisile spent living apart took a toll upon their marriage and they would often disagree and argue. Once, when they argued, he told her that 'he had needs' 'like all men do'. So he decided to take a 'city wife' as many of his friends had done. Sadly, his city wife was HIV-positive and when Mxolisi returned home one December, himself HIV-positive by this time, he gave Vuyisile another child, Thandi (which means 'nurturing love'), but he also gave her the killer virus that would take both their lives.

Mxolisi and Vuyisile discovered that they were HIV-positive in the year Nosipho turned 8 years old. Andile was 5 and little Thandi only 2 . Thandi had already been infected with the virus her mother was carrying through breastfeeding. Sadly, both Mxolisi and Vuyisile died of AIDS within 3 years of discovering their status. Thandi, however, is still alive and now a little girl of 5 years old.

Nosipho is a clever little girl. However, she has not been to school since her father died when she was 11 years old. By that stage her mother was already very ill and confined to bed, but at least Andile and Thandi could stay with their mother, while Nosipho begged for food and money at a traffic intersection on the edge of the township. She watched the other children going to school dressed in their smart school uniforms, with book bags that had pencils, paper and, no doubt, some lunch to eat. She wished that she could be like them, but that would not happen. Her mother eventually also died.

Tonight, as Nosipho lay in bed, she was no longer a child, but a parent. Overnight she had become a 13 year old head of a household of three. She knew that she had a much greater responsibility than other 13 year old children. Each day she has to get enough money from the cars and commuters that come whizzing by to feed her two siblings and herself. She has a small cardboard sign on which she has written in a child's handwriting 'No parents, no food, no work, 3 people to feed. Please help. God bless you'. She also needs to get some extra money every month to help pay for Andile's school fees. She wants him to stay in school and learn so that he does not have to suffer like his father did. She does not want him to suffer like she is suffering now. Whatever money she has left after she has paid his fees, if any, is given to the 'aunty' who looks after her sick sister, Thandi, while Andile is at school and she is begging at the traffic lights. Nosipho does not trust the aunty, because she drinks, and Nosipho is sure that she hits Thandi. She has, however, no option. It is too dangerous for Thandi to be with her at a busy traffic intersection.

There are other girls like Nosipho. In fact most of the child headed households in South Africa are headed by girls under the age of 15. Nosipho knows this, because she meets some of them every Sunday at the tin church near her shack. They assembled in a small group for children like her. They sing songs, listen to stories from the Bible, read to them by some kind ladies, and then they say prayers and get some food to eat. The church has also given her and her brother and sister some clothes and shoes. There is a lady from the government 
clinic who comes to visit their group once a month. She always asks Nosipho if she is safe and if she and her brother and sister are getting enough to eat. Thandi needs special medicine to keep her healthy, but she can only take her medicine if she eats properly, or else the medicine will make her sick instead of healthy. On days when Nosipho does not get enough money or food to feed all three of them, she lets Thandi eat first so that she can take her medicine. Andile eats next, because he cannot learn when his stomach is empty. Nosipho often lies awake at night hungry, but she knows that she is a 'gift' from her parents to Andile and Thandi - that is what her name means. It is the name her father gave her. She does not play anymore - she simply lives to be a gift to her brother and sister. Tonight she prayed to ask God to help her, because a man has said he will give her R20 if she takes off her clothes and sleeps with him. She prayed, because she is afraid. She has been told at church and she has seen the posters and heard the stories that this is how little girls get sick and die, but she needs the money. She wants to be a gift. She does not know what to do. Maybe God will do something to help her tomorrow. Tomorrow is Sunday and she will ask one of the ladies to help her.

This narrative illustrates in a very powerful way just how correct Wils $(2016: 1,10)$ is in reminding us that when we consider the impact of social issues on health, medical ethics that only engages 'health care' could never be enough. Indeed, medical ethics must help us to move from a consideration of 'just health care' (Wils 2016:10) to considering the far more important issue of a socially embedded notion of 'just health' (pp. 10-11).

\section{Health and the public good: The problem of inequality}

A pertinent aspect of this discussion, extrapolated from Wils' article (2016:11), is how the problem of social, economic and gender inequality compounds the injustice of the commodification of health care and privatisation of the 'public good' of just health.

Wils' article was first presented at a conference at Stellenbosch University in August 2015. The social location of that conference was deeply poignant, because Stellenbosch is the most unequal city in the world. It is widely known that South Africa has one of the highest rates of economic inequality in the world (Bowers du Toit \& Nkomo 2014:1-8; cf. Nattrass \& Seekings 2001:45-50; Ozler \& Hoogeveen 2005:45-48; Seekings \& Nattrass 2008; Terreblanche 2002). Within South Africa there is no city that is more unequal than Stellenbosch. ${ }^{4}$

The reality is that South Africa has two very different systems of health care and two very different realities of health (cf. Nattrass \& Seekings 2001:45-70). For the wealthy there are private medical aid schemes, private hospitals that are

4. Refer to the succinct discussion of income inequality within the Stellenbosch municipal area in Sustainable Stellenbosch: Opening dialogues (Swilling Sebitosi \& municipal area in Sustainable Stellenbosch: Opening dialogues (Swilling, Sebitosi \& Loots 2012:23), simply stated three of South Africa's richest families live within this municipal district. Their combined wealth equals more than the combined wealth of half of South Africa's population (Anon 2015). well-equipped, fitted with the latest equipment, not overburdened with excessive patient loads, and staffed by well-trained and largely well-paid and motivated health care professionals. For the poor there is the basic health care system of state hospitals and local community clinics that offer free or very affordable emergency medical care and basic health care. These institutions are frequently understaffed, undersupplied with medical equipment and lacking the capacity to adequately serve the large numbers of people that rely on them - much like the examples cited in Wils' article (2016:2) that took place in Greece after the economic collapse in 2012 (also see Stuckler \& Basu 2013). Moreover, there are instances in which corruption and negligence contribute to poor service delivery. Some may argue that this is a return to an argument for just health care.

However, as Wils (2016:8-10) mentions in his nine points on the phenomenology of health, when one considers the phenomenon of health it becomes even more evident that points such as one's geographical location (point 4), environmental concerns (point 5), social position (point 6), living conditions (point 7), working conditions and educational level (point 8), and the quality and state of the health care system (point 9) are critical to not only how one will understand the phenomenon of health, but what one can do to facilitate a measure of just health for one's self and one's community.

To my mind, these points are critical as diagnostic tools (to use a medical metaphor), but also as aspirations of possibilities for just health if framed in a positive sense. They help us to understand the truth of how unjust and unequal our experience of the health phenomenon (and by extension health care) is in South Africa where persons are separated economically, geographically, educationally and in terms of class. Of course, this also carries over into the issue of an unjust provision of health care, which our context shows we do not regard as a 'public good' (Wils 2016:10).

In August 2011 the South African government released a Green Paper that proposed the introduction of National Health Insurance in South Africa that would seek to raise the standard of national health care for all citizens and restrict the capacity of the private health care sector to commercialise and privatise health care. However, because the private health care sector is such a significant contributor to the Gross Domestic Product (GDP), this project faced massive opposition from powerful and wealthy groups (Mashego 2016). It has been cited as an example of social and economic inequality and shown to be shrouded in political mystery, subject to those who hold wealth and power in the South African society (Mashego 2016).

\section{Just health and the oikonume: Empire, economics and apathy}

The previous discussion showed the intersectional nature of just health and economic considerations. One pertinent example will suffice to highlight this issue. In 2003, at the 
height of the Mbeki administration's AIDS denialism when thousands of people were dying each day because the South African government refused to roll out anti-retroviral medication, Mr Trevor Manuel, then Minister of Finance, said the following in parliament (in Gumede 2007):

\footnotetext{
... the 'rhetoric' about the effectiveness of ARV's is a lot of voodoo... buying them would be a waste of time and limited resources. It does not make sense to spend money on people dying anyway, who are not even productive in the first place. (p. 201, [author's italics]; also refer to Feinstein 2007:140-141)
}

However, the issue was not only a matter of economics. There were two other contributors that compounded the suffering of the sick. These can be labelled as the trio of empire, economics and apathy (Forster 2011:71-96).

We have already touched briefly on economics as an intersectional component of just health. The next contributor was what Wils (2016:1-2) refers to as the political nature of health and health care. This can be related to the concept of empire in contemporary theological discourse. Rieger (2007:2-3) writes that 'Empire seeks to extend its control as far as possible ... intellectually, emotionally, psychologically, culturally, and religiously.' The Mbeki administration was widely criticised across the world for questioning (and even denying) the link between HIV and AIDS (Boseley 2008; Nattrass 2007; cf. Schneider \& Fassin 2002:545-551).

The project of the empire was to downplay and deny the point that persons would contract HIV through sexual contact, which, if it was left untreated, would develop into AIDS from which persons would eventually die. Rather, they stated that the primary cause of death was economic deprivation and that it had nothing to do with sexually acquired HIV. Wils (2016:2) stated, citing the example of Greece (Stuckler \& Basu 2013), that healthcare becomes a 'Politics of life and death'. Indeed, something similar was happening in South Africa: because of political ideology thousands, perhaps even hundreds of thousands, of persons died from a disease that could have been treated and managed if there had been an understanding of 'just health'. Professor Malegapuru Makgoba (2002:1903), a leading scientist and former head of the Medical Sciences Research Council, noted that, because of its political campaign and the sending of mixed messages on HIV and AIDS, the South African government had collaborated 'in the greatest genocide of our time' (also see Feinstein 2007:137).

A third contributor, among many other possibilities, to unjust health in South Africa during that period was what came to be termed as apathy. Wils' (2016:2-3) reminded us of the critical 'virtue of solidarity' in relation to just health. The Belgian theologian Edward Schillebeeeckx, who was Professor of Theology at Radboud University, notes that without true solidarity the 'gospel becomes impossible to believe and understand' (Schillebeeckx 1981:623). Indeed, how is it possible that we would allow such inequality and injustice to exist in a country where $79.8 \%$ of the population identify themselves as Christians? Denis argues that, when HIV and AIDS first began to spread in South Africa, Christians did not believe that it was 'our problem'. Philipe Denis, a Professor of History at the University of KwaZulu Natal was the first person to write a comprehensive history of the South African Church's response to HIV and AIDS (cf. Denis 2009). He highlights the sad reality that even more powerful than economics was the issue of stigma. First, Christians and the church saw HIV as a disease of sexual deviance (contracted through male homosexual intercourse). Next, when they realised that heterosexual women were more likely to be infected than homosexual males, they viewed it as a disease of sexual promiscuity. Later still, when such a theology of blame could not be sustained, because so-called 'innocents' were contracting the disease (through needle stick injuries or mother to child transmission), the church began to awaken to the fact that the separation between one's self and the 'other' was not so clear. As with HIV itself - when one part of the body is infected the whole body is affected. It was only in 2005 that South Africa's largest mainline Christian denomination, the Methodist Church of Southern Africa, adopted a slogan: 'The Church has AIDS', adapted from the first letter to the Corinthians by saying, 'We care. "When one part of the body is affected the whole body suffers" 1 Corinthians 12:26' (Forster 2010a:83).

Had the church in South Africa been in solidarity with its own members, indeed with broader society, at an earlier stage in the pandemic, thousands of lives could have been saved, and the suffering of many more could have been limited.

\section{Conclusion}

This article has sought to contextualise and appreciate one of the central arguments of Jean-Pierre Wils' article on the future of medical ethics. It has been argued that the South African contextual reality supports the notion that the future of medical ethics, certainly in this context, will need to engage critically with what it means to understand just health as a public good. It was argued that the Christian church has a public theological responsibility to seek a different oikonume [a management of the resources of the household of God] that engages neo-liberal capitalism (Wils 2016:11). However, one is left wondering who will facilitate, perhaps even provide, this more just health care in a nation with a failing state and increasing economic and racial inequality? It is contended that in light of this there is still an important role for Christians and the church to play as agents of wholeness and healing in society. Perhaps it is time to subvert empire and economics by overcoming our apathy, and re-establishing a just ethics of health that can be evidenced in the rich tradition of health care and education provided by the churches in South Africa which was masterfully dismantled by the apartheid system. 


\section{Acknowledgements Competing interests}

The author declares that he has no financial or personal relationships which may have inappropriately influenced him in writing this article.

\section{References}

Anon., 2015, 'South Africa's two richest people have wealth equal to the poores 26.5-million', 702 Cape Talk Radio, 29 January, viewed 29 January 2015 from http://www.702.co.za/articles/634/south-africa-s-two-richest-people-havewealth-equal-to-the-poorest-26-5-million

Barlow, J., Forster, D.A., Kamara, E.K., Molatji, N.J., Newell-Jones, K., Raja, J.J. \& Tuckey, C., 2010, 'ISG 44: Church Communities Confronting HIV/AIDS' in G.B. Byamugisha (ed.), International Study Guide, pp. 5-8, SPCK, London.

Boseley, S. 2008, 'Mbeki Aids denial "caused 300,000 deaths"', The Guardian, 26 November, viewed 16 March 2016, from https://www.theguardian.com/ world/2008/nov/26/aids-south-africa

Bowers du Toit, N.F. \& Nkomo, G., 2014, 'The ongoing challenge of restorative justice in South Africa: How and why wealthy suburban congregations are responding to poverty and inequality', HTS Theological Studies, 70(2), Art. \#2022, 8 pages. http://dx.doi.org/10.4102/hts.v70i2.2022

Denis, P., 2009, 'The church's impact on HIV prevention and mitigation in South Africa: Reflections of a historian', Journal of Theology for Southern Africa 134(1), 66-81.

Feinstein, A., 2007, After the Party: Corruption, the ANC and South Africa's Uncertain Future, Verso Books, London.

Forster, D.A., 2010a, Christian and Positive: Reflections on Christianity in an HIV+ World, MMA Publishers, Cape Town.

Forster, D.A., 2010b, 'World AIDS day - I am positive', viewed 31 March 2016, from http:// www.dionforster.com/blog/2010/12/1/world-aids-day-i-am-positive.html
Forster, D.A., 2011, 'Empire, Economics and Apathy: A theological reflection on suffering as a result of HIV/AIDS', in L.R. Withrow (ed.). Alienation and Connection: suffering as a result of HIV/AIDS, in L.R. Withrow (ed.), Alienation and
Suffering in a Global Age, pp. 71-96, Lexington Books, Lanham, MD.

Gumede, W.M., 2007, Thabo Mbeki and the Battle for the Soul of the ANC, Zed Books, London.

Hendriks, J. \& Erasmus, J., 2005, 'Religion in South Africa: 2001 population census data', Journal of Theology for Southern Africa, 121(1), 88-111.

Makgoba, M.W., 2002, 'Politics, the media and science in HIV/AIDS: the peril of pseudoscience', Vaccine 20(15), 1899-1904.

Mashego, P., 2016, Expensive private healthcare highlighted at inquiry', Business Day Live, viewed 16 March 2016, from http://www.bdlive.co.za/national/ health/2016/02/18/expensive-private-healthcare-highlighted-at-inquiry

Nattrass, N., 2007, Mortal Combat: AIDS Denialism and the Struggle for Antiretrovirals in South Africa, University of KwaZulu-Natal Press, Pietermaritzburg.

Nattrass, N. \& Seekings, J., 2001, “'Two nations"? Race and economic inequality in South Africa today', Daedalus, 130(1), 45-70.

Nieman, A. 2010, 'Churches and social development in South Africa' in I.W. Swart, S. Green \& J. Erasmus (eds.), Religion and social development in post-apartheid South Africa Stellenbosch, pp. 37-44, SUN Press, Stellenbosch.

Ozler, B. \& Hoogeveen, J.G.M., 2005, 'Not separate, not equal: Poverty and inequality in post-apartheid South Africa', viewed 16 March 2016 from http://papers.ssrn. com/sol3/papers.cfm?abstract_id=669147

Rieger, J., 2007, Christ \& Empire: From Paul to Postcolonial Times, Fortress Press, Philadelphia, PA.

Schillebeeckx, E., 1981, Jesus: An Experiment in Christology, Crossroad, New York.

Schneider, H. \& Fassin, D., 2002, 'Denial and defiance: a socio-political analysis of AIDS in South Africa', Aids 16(4), 545-551.

Seekings, J. \& Nattrass, N., 2008, Class, Race, and Inequality in South Africa, Yale University Press, New Haven, CT.

Stuckler, D. \& Basu, S., 2013, The Body Economic: Why Austerity Kills - Recessions, Budget Battles, and The Politics of Life and Death, HarperCollins, New York.

Swilling, R., Sebitosi, B. \& Loots (eds.), 2012, Sustainable Stellenbosch: Opening Dialogues, African SUN MeDIA, Stellenbosch.

Terreblanche, S.J., 2002, A History of Inequality in South Africa, 1652-2002, University of Natal Press, Pietermaritzburg.

Wils, J.P., in press, "Is there a future for 'medical ethics?", In die Skriflig/In Luce Verbi 50(1). 